\title{
Bat diversity of Ilha da Marambaia, Southern Rio de Janeiro State, Brazil (Chiroptera, Mammalia)
}

\author{
Lourenço, EC.*, Costa, LM., Silva, RM. and Esbérard, CEL. \\ Laboratório de Diversidade de Morcegos, Universidade Federal Rural do Rio de Janeiro - UFRRJ, \\ CP 74507, CEP 23851-970, Seropédica, RJ, Brazil \\ *e-mail: beteclouren1205@yahoo.com.br \\ Received February 16, 2009 - Accepted July 28, 2009 - Distributed August 31, 2010
}

(With 2 figures)

\begin{abstract}
Few sites have been well sampled for bats, and samplings in islands are even scarcer. Therefore, the objectives of the present study were: (1) to list the bat species of Ilha da Marambaia; (2) to compare richness, abundance and biomass of bat guilds found there; (3) to analyse abundance patterns of bat species; and (4) to compare richness, abundance and composition of the bat fauna among different kinds of environment. To capture bats we used mist nets set in five different environments, totalising 3559.2 net-hours, during 37 nights between October 2006 and August 2008. A total of 1,133 captures were accomplished, comprising 34 species from five families. The most abundant species was Molossus molossus. Frugivorous bats exhibited higher richness, abundance and biomass if compared to other guilds. Most species $(\mathrm{N}=22)$ exhibited abundances between 1 to $10 \%$ of all captures. Sixteen species were restricted to just one of the environments sampled. The high richness may be attributed to sampling carried out in several environments, and to the capture of insectivorous species over water bodies.
\end{abstract}

Keywords: abundance, captures, sampling effort, survey methods.

\section{Diversidade de morcegos da Ilha da Marambaia, Sul do Rio de Janeiro, Brasil (Chiroptera, Mammalia)}

\begin{abstract}
Resumo
Poucos são os locais satisfatoriamente amostrados para morcegos e menos ainda as ilhas. Os objetivos deste estudo foram listar as espécies de morcegos da Ilha da Marambaia, comparar a riqueza, abundância e biomassa das guildas de morcegos encontradas, analisar o padrão de abundância das espécies de morcegos e comparar a riqueza, abundância e composição entre os diferentes ambientes amostrados. O método de amostragem consistiu do uso de redes de neblina armadas em cinco ambientes diferentes, totalizando 3559,2 redes-hora, em 37 noites entre outubro de 2006 e agosto de 2008. Foram obtidas 1.133 capturas, compreendendo 34 espécies de cinco famílias. A espécie mais abundante foi Molossus molossus. Os frugívoros apresentaram maior riqueza, abundância e biomassa. A maior parte das espécies $(\mathrm{N}=22)$ apresentou abundâncias entre 1 e $10 \%$ do total de capturas. Dezesseis espécies foram restritas a apenas um dos ambientes amostrados. A elevada riqueza encontrada pode ser atribuída à realização de coletas em vários ambientes, e a captura de espécies insetívoras sobre a água.
\end{abstract}

Palavras-chave: abundância, capturas, esforço amostral, métodos de amostragem.

\section{Introduction}

The largest extension of continuous forest in Rio de Janeiro State is located in the Southern region, which harbours most of the still well-preserved Atlantic Forest remnants (Fidalgo et al., 2007). It is an area of high interest for conservation, which has been pointed out for a higher sampling effort due to its large forest cover and to the reduced mammal sampling yet performed (Bergallo et al., 2000). Few published studies have assessed mammal richness and abundance in the area.
For bats, there have already been some inventories published, but not all are satisfactory. On Ilha Grande, in the municipality of Angra dos Reis, there is a list with over 3,000 captures and 36 bat species captured during seven years of sampling work (Esbérard et al., 2006). In Rio das Pedras Reserve, Mangaratiba municipality, 26 bat species were listed after 1,287 captures (Esbérard and Bergallo, 2008a; Esbérard, 2009). On Ilha da Gipóia, Angra dos Reis municipality, 27 species were recorded after 
1,776 captures (Esbérard, 2009). On Ilha da Marambaia, Enseada de Sepetiba (Marambaia Island, Sepetiba Creek), there is a previous list with 16 bat species, carried out between 1991 and 1998 (Costa and Peracchi, 2005). Vampyrodes caraccioli (Thomas, 1889) was recently added to the fauna of Rio de Janeiro State (Bezerra et al., 2004; personal communication) and Peracchi and Nogueira (2008) recorded the occurrence of this species at Ilha da Marambaia, increasing to 17 species its bat fauna. The number of species found on Ilha da Marambaia is low if compared to other inventories in the region and in the Atlantic Forest (see Peracchi and Albuquerque, 1993; Esbérard et al., 1996; Reis et al., 1996; Taddei and Pedro, 1996; Baptista and Mello, 2001; Dias et al., 2002; Esbérard, 2003) which suggests that continuous sampling and an increase in sampling effort could result in a higher richness.

Therefore, the objectives of the present study were: (i) to continue the inventory of bat species of Ilha da Marambaia; (ii) to analyse richness, abundance and biomass of different trophic guilds; (iii) to analyse the abundance pattern of bat species, and (iv) to compare richness, relative abundance and composition between different environments sampled.

\section{Methodology}

Ilha da Marambaia is located in the Sepetiba bay, on the Southern coast of Rio de Janeiro State $\left(23^{\circ} 04^{\prime} \mathrm{S}\right.$ and $43^{\circ} 53^{\prime} \mathrm{W}$ ) (Figure 1). The island is $42 \mathrm{~km}^{2}$ and has a sand zone of around $40 \mathrm{~km}$ in extension, called Restinga da Marambaia (Marambaia Coastal Restinga), which is connected to the continent and to the municipality of Rio de Janeiro (Conde et al., 2005). The regional climate is classified as tropical wet (Koopen's Aw); July is the coldest month (average of $16.8^{\circ} \mathrm{C}$ ), whereas February is the warmest (average of $32.3^{\circ} \mathrm{C}$ ). From November to March the average rainfall exceeds $100 \mathrm{~mm}$. Nearly $37 \%$ of the average annual rainfall $(1,240 \mathrm{~mm})$ occurs during summer; March is the wettest month and July is the driest (Mattos, 2005). Ilha da Marambaia has a large portion of its area covered by forest remnants, similar to continuous areas on the continent, plus patches of mangrove, and costal sand dune-shrubby restinga (Menezes and Araújo, 2005). During colonial times, the island was occupied by European settles that developed some farming activities, and the forest facing the continent has suffered different degrees of deforestation (Pereira et al., 1990), and today is in a state of secondary growth (Conde et al., 2005). Despite the long occupation, the island and sand dune vegetation (Restinga) are relatively well-preserved (Conde et al., 2005). The restricted military usage of the area, added to the fact that the region is officially protected as an Environmental Protection Area (Área de Proteção Ambiental de Mangaratiba - Decreto 9.802 de 1987) ensures its continued preservation (SEMADS, 2001).

Sampling was carried out on two or three consecutive nights each month, between October 2006 and August 2008
(37 nights and 390 hours). Mist nets were opened all night long (12 hours) following recommendations by Esbérard and Bergallo (2006), in all moon phases (Esbérard, 2007) and under different climate conditions, even during rainy nights. The sampling effort was calculated in net-hours, one net-hour corresponding to each mist net $(9 \times 2.5 \mathrm{~m}$, $20 \mathrm{~mm}$ mesh) opened each hour (sensu Sampaio et al., 2003). Each night we used from 6 to 13 nets, resulting in a total sampling effort of 3559.2 net-hours.

We surveyed different environments on the island, and these were grouped, in order to compare richness, abundance and composition, into the following categories: (i) Dam- Impoundment of streamlet, forming a platform $50 \mathrm{~m}$ long, 70-80 $\mathrm{m} \mathrm{ASL}$, and situated above $5 \mathrm{~m}$ water level, with earlier secondary forest with open canopy, 5-10 m high dominated by Cecropia, Ficus and Guarea (sampling effort of 15 nights and 1310.3 net-hours); (ii) Trails-Trails 1 to $2 \mathrm{~m}$ wide inside the forest, route of the access point tour of the island bordered with initial secondary vegetation with 10-15 m high open canopy revealing samples of Ficus, Myrtaceae and Melastomataceae (sampling effort of 11 nights and 611.2 net-hours); (iii) Delta river- Streamlet communication on beach, with Mangrove vegetation predominance at edges (Avicenia schueriana Stapf and Leechman - Avicenniaceae, Laguncularia racemosa (L.) Gaerten - Combretaceae, Rhizophora mangle L. - Rhizophoraceae) with Terminalia catappa
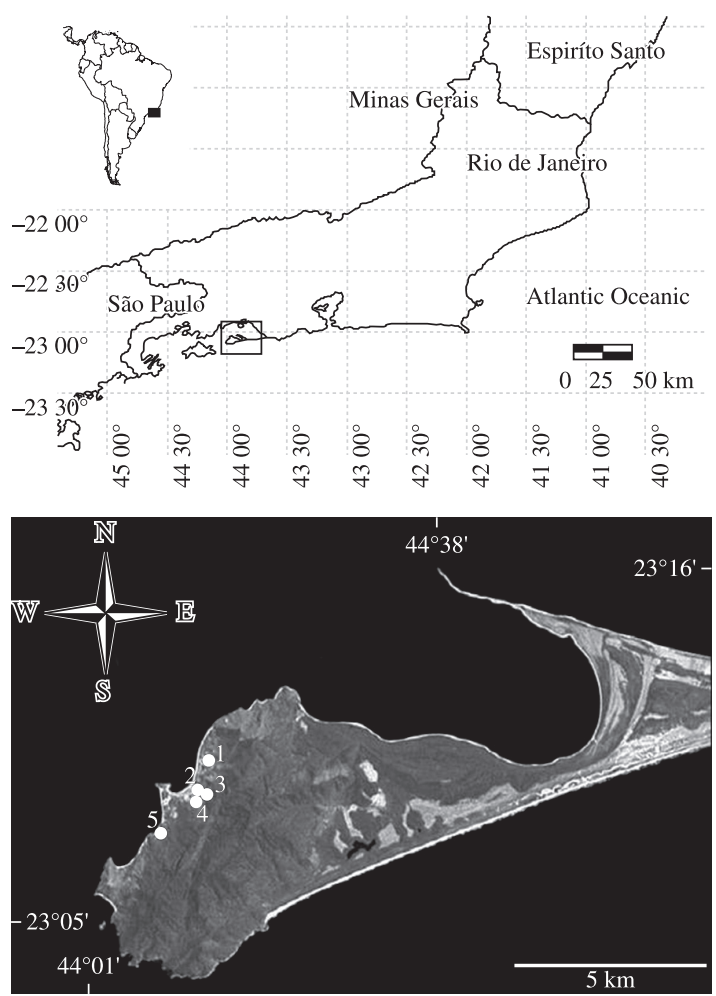

Figure 1. South America, Rio de Janeiro State, detail of Ilha da Marambaia with sampling points: 1 - Residences, 2 - Dam, 3 - Trail, 4 - Streamlet, 5 - Delta river. 
L. (Combretaceae) and some typical restinga species (Cactaceae and Bromeliaceae) near houses of fisherman (30 to $50 \mathrm{~m}$ far from nets) (sampling effort of eight nights and 672.5 net-hours); (iv) Streamlet-Streamlet that has a sandy bed after removal of rocks and ends in the dam, inside the secondary forest with 15-20 m high canopy with predominance of Myrtaceae and Melastomataceae (sampling effort was four nights and 205 net-hours); (v) Between residences- Three backyards, with predominance of fruiting trees, ornamental plants and much bamboo (Bambusa) with presence of domestic animals (chickens, dogs, pigs). No continuous source of electric lighting in these houses, but several impacts are observed such as the burning of garbage, deforestation and destruction of pond (sampling effort was seven nights and 760.2 net-hours).

The sampling sites considered here are located in the surroundings of the Training Centre of Marambaia Island (Centro de Adestramento da Ilha da Marambaia). The most distant sites - residences and river delta - are ca. 1,500 $\mathrm{m}$ apart from each other, whereas most of the other sampling sites are at a linear distance of 100-200 m from each other.

Bats captured in the nets were weighed on an electronic weighing scale $(0.1 \mathrm{~g})$, had their forearm measured with a caliper $(0.1 \mathrm{~mm})$, were individually marked with plastic necklaces with coloured cylinders (Esbérard and Daemon, 1999), and were released at the capture site. All bats were released, except for one or two specimens per species that were deposited as vouchers in the collection of in the Bat Diversity Lab (Laboratório de Diversidade de Morcegos) at the Universidade Federal Rural do Rio de Janeiro: Anoura caudifer (E. Geoffroy, 1818) LDM 4591 ऽ// LDM 4371 , Anoura geoffroyi Gray, 1838 LDM 5067 q, Artibeus fimbriatus Gray, 1838 LDM 1033 §/ LDM 4559 ㅇ, Artibeus lituratus (Olfers, 1818) LDM $4375 \precsim /$ LDM 4363 ㅇ, Artibeus obscurus (Schinz, 1821) LDM $4353 \approx /$ LDM 4563 \& , Artibeus planirostris (Spix, 1823) LDM 4582 ㄱ/ LDM 5080 으, Carollia perspicillata (Linnaeus, 1758) LDM 4350 ㅇ/ LDM 4355 ㅇ, Chiroderma doriae Thomas, 1891 LDM 4352 9 , Chiroderma villosum Peters, 1860 LDM 4380 ऊ/ LDM 4358 ㅇ, Cynomops abrasus (Temminck, 1827) LDM $4943 \delta$ / LDM 4906 ,

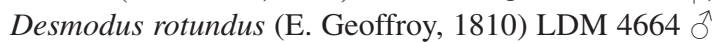
/ LDM 4705 옴, Diaemus youngi (Jentink, 1893) LDM 4314 đ., Eptesicus brasiliensis (Desmarest, 1819) LDM 5030, Glossophaga soricina (Pallas, 1766) LDM 4327 శึ / LDM 4590 , Lasiurus blossevillii (Lesson and Garnot, 1826) LDM $4663 \hat{\jmath}$, Lasiurus ega (Gervais, 1856) LDM 4703 ㅇ, Lonchophylla bokermanni Sazima, Vizotto and Taddei, 1978 LDM 4424 ㅇ , Micronycteris megalotis (Gray, 1842) LDM 5012 ๙ / LDM 4331 q , Molossus molossus (Pallas, 1766) LDM $4702 \precsim /$ LDM 4662 의, Molossus rufus E. Geoffroy, 1805 LDM 4551 శ/ LDM 4554 ㅇ , Myotis nigricans (Schinz, 1821) 4334 q / 4293 + , Myotis riparius Handley, 1960 LDM $4290 \precsim /$ LDM 4291 q, Noctilio leporinus (Linnaeus, 1758) LDM 4881 §ै। LDM 4428 ㅇ, Nyctinomops laticaudatus (E.Geoffroy, 1805) LDM $4428 \hat{\jmath} /$ LDM $4881 \hat{\jmath}$, Nyctinomops macrotis (Gray,

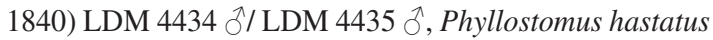

(Pallas, 1767) LDM 4511 $/$ LDM 4378 , Platyrrhinus lineatus (E. Geoffroy, 1810) LDM 4667 ㅇ/LDM 4345 ㅇ, Platyrrhinus recifinus (Thomas, 1901) LDM $4342 \pi /$ LDM 4357 ㅇ, Saccopteryx leptura (Schreber, 1774) LDM 4438 7 , Sturnira lilium (E. Geoffroy, 1810) LDM 5072 \&/ LDM

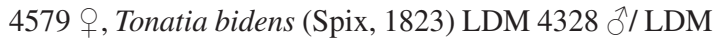
4351 ㅇ, Trachops cirrhosus (Spix, 1823) LDM 4313 이 LDM 4384 9, Vampyressa pusilla (Wagner, 1843) LDM $4349 \widehat{\jmath} /$ LDM 4348 ㅇ, Vampyrodes caraccioli (Thomas, 1889) LDM 4382 ふै/ LDM 4383 ㅇ.

The bats captured were identified in field using bibliographic sources (Vizotto and Taddei, 1973; Marques-Aguiar, 1994; Medellin et al., 1997; Simmons and Voss, 1998; Gregorin and Taddei, 2002). The taxonomic arrangement and the nomenclature of species follows Simmons (2005).

The local richness of Ilha da Marambaia was estimated using the method of empiric abundance based on the occurrence of rare species (Chao, 1984). The species accumulation curve (Sóberon and Llorente, 1993) was calculated based on total captures (Colwell, 2005) and carried out for the island as a whole. For the three environments with higher sampling effort the species accumulation curve was calculated by randomisation based on total captures, using the program EstimateS for Windows 7.5 (Colwell, 2005).

Species were grouped into major foraging guilds according to Kalko et al. (1996) in order to compare richness, abundance and biomass. The average forearm length and the biomass of the sample (95\% confidence interval) were presented. In the calculation of biomass, pregnant females and the weight and forearm length of youngs were not considered to avoid variations that not represent the adult measures of the bats. An analysis to obtain the abundance pattern of bat species was carried out for the whole island, with total captures being divided into logarithmic classes: rare (0-0.1\% of captures), less abundant $(0.1-1 \%)$, abundant $(1-10 \%)$ or very abundant (10-100\%) (Esbérard, 2009).

Since the sampling effort carried out in each site was uneven, and in each sampling more than one environment may be simultaneously sampled, the abundance of each species was divided by the sampling effort (total captures divided by sampling effort using as unit captures/net-hours). For the five sampled environments the Margalef richness index (Magurran, 1988) was calculated and differences tested by the Student Test (Zar, 1999). The qualitative similarity, considering only the presence/absence of species, was performed using the Jaccard coefficient (Magurran, 1988) and was calculated between environments. Samplings carried out in residence surroundings were not considered in the similarity comparisons because they involved more than one site.

\section{Results}

We analysed 1,133 captures, comprising 34 species from five families (Emballonuridae, Phyllostomidae, Noctilionidae, Molossidae and Vespertilionidae) (Table 1). The most common species was Molossus molossus which 
Table 1. Bats of Ilha da Marambaia, total females and males and the numbers between parentheses indicates the young, with respective biomass and length of forearm. Sd - standard deviation. Variance - minimum and maximum in the $95 \%$ confidence interval. Weight of gravid females and weight and forearm length of young were not included. (*) indicates the species recorded earlier in the island by Costa and Peracchi (2005) and Peracchi and Nogueira (2008).

\begin{tabular}{cccccc} 
Taxa & Male Female & \multicolumn{2}{c}{ Biomass } & & Forearm \\
\cline { 3 - 5 } & & N & Average $\pm \quad$ Variance & & Average \pm Variance
\end{tabular}

Emballonuridae

Saccopteryx leptura

Phyllostomidae

Desmodontinae

\section{Desmodus rotundus*}

Diaemus youngi

Glossophaginae

Anoura caudifer

Anoura geoffroyi

Glossophaga soricina *

Lonchophylla bokermanni

Phyllostominae

Micronycteris megalotis*

Phyllostomus hastatus*

Tonatia bidens*

Trachops cirrhosus*

Carolliinae

Carollia perspicillata*

Sternodermatinae

Artibeus fimbriatus

Artibeus lituratus*

Artibeus obscurus*

Artibeus planirostris

Chiroderma doriae

Chiroderma villosum

Platyrrhinus lineatus*

Platyrrhinus recifinus

Sturnira lilium *

Vampyressa pusilla

Vampyrodes caraccioli *

Noctilionidae

Noctilio leporinus *

Molossidae

Molossinae

Cynomops abrasus

Molossus molossus*

Molossus rufus

Nyctinomops laticaudatus

Nyctinomops macrotis

Vespertilionidae

Verpetilioninae

Eptesicus brasiliensis

Lasiurus blossevillii

Lasiurus ega

Myotinae

Myotis nigricans*

Myotis riparius
SD SD

42.3

5.6

1

$\begin{array}{cccccccc}15 & 11 & 26 & 37.2 \pm 6.1 & 34.7-39.7 & 26 & 63.1 \pm 2.5 & 62.1-64.1 \\ - & 1 & 1 & 41.8 & - & 1 & 55.1 & - \\ 10 & 3 & 10 & 11.8 \pm 1.6 & 10.6-12.9 & 12 & 37.4 \pm 0.8 & 36.9-37.9 \\ - & 1 & & 38.0 & - & & - & - \\ 2 & 1 & 3 & 11.2 \pm 1.1 & 8.4-14.0 & 3 & 36.1 \pm 0.5 & 34.8-37.4 \\ - & 1 & 1 & 9.2 & - & 1 & 36.3 & -\end{array}$

$\begin{array}{cc}- & 4(1) \\ 12 & 7 \\ 10 & 11 \\ 4 & 2\end{array}$

$54 \quad 55$

$\begin{array}{cccc}8 & 23 & 24 & 60.8 \pm 12.2 \\ 62 & 57 & 114 & 75.3 \pm 10.8 \\ 45 & 95(2) & 94 & 38.2+5.2 \\ 36(1) & 102(1) & 98 & 40.8 \pm 7.7 \\ (1) & - & & -\end{array}$

55.6-65.9

73.2-77.2

$37.1-39.2$

39.2-42.3

$\begin{array}{llll}- & 2 & 2 & 28.0 \pm 4.2\end{array}$

$\begin{array}{llll}23 & 18 & 38 & 28.2 \pm 9.1\end{array}$

$\begin{array}{llll}15 & 14 & 24 & 18.2 \pm 4.3\end{array}$

$\begin{array}{llll}11(1) & 12(1) & 21 & 19.0 \pm 5.9\end{array}$

$\begin{array}{llll}1 & 5 & 5 & 9.1 \pm 1.5\end{array}$

8 (2) $\quad 4 \quad 11 \quad 35.7 \pm 5.1$

$\begin{array}{llll}5 & 3 & 8 & 78.9 \pm 17.6\end{array}$

64.1-93.6

4

$35.3 \pm 0.5$

$34.4-36.2$

19

$87.0 \pm 3.1$

$85.5 \pm 88.5$

20

$57.7 \pm 1.2$

$51.1-52.2$

$22.6-25.8$

$56.0 \pm 4.2$

$51.6-60.4$

25.2-31.2

16.4-20.1

16.3-21.6

7.1-11.1

32.3-39.2

$39.9 \pm 1.8$

$39.5-40.3$

25

$66.9 \pm 2.4$

$65.9-67.9$

$115 \quad 72.6 \pm 2.5$

$72.1-73.1$

$96 \quad 57.7 \pm 3.6$

$57.0-58.4$

101

$60.2 \pm 2.0$

$59.6-60.4$

$\begin{array}{ll}2 & 49.5 \pm 2.1\end{array}$

$39 \quad 48.1 \pm 2.0$

$24 \quad 42.2 \pm 1.2$

$\begin{array}{ll}22 & 43.2 \pm 1.8\end{array}$

$5 \quad 33.6 \pm 0.7$

$12 \quad 53.792 .6$

47.4-48.7

41.6- 42.7

42. $4-44.0$

32.8-34.5

52.0-55.3

8

$88.3 \pm 2.8$

86.0-90.6

$\begin{array}{cccc}1 & 1 & 2 & 25.0 \pm 1.4 \\ 185 & 81 & 244 & 16.0 \pm 3.1 \\ 6 & 5 & 11 & 34.3 \pm 5.5 \\ 8 & 19 & 26 & 15.4 \pm 4.0 \\ - & 2 & 2 & 27.5 \pm 3.5\end{array}$

$15.6-16.4$

$\begin{array}{ll}2 & 42.3 \pm 0.4\end{array}$

30.5-38.0

$248 \quad 38.7+1.3$

38.5-38.9

13.7-17.0

$52.1+1.0$

51.4-52.7

$27 \quad 45.2 \pm 7.9$

44. $4-46.0$

$2 \quad 62.5 \pm 2.1$

9.1

13.0

13.0

41.5

40.5

47.1

$\begin{array}{ll}1 & 41.5 \\ 1 & 40.5 \\ 1 & 47.1\end{array}$

\begin{tabular}{cccccccc}
7 & 16 & 23 & $4.9 \pm 1.2$ & $4.4-5.4$ & 22 & $32.9 \pm 0.8$ & $32.6-33.3$ \\
14 & 21 & 34 & $5.4 \pm 2.3$ & $4.6-6.2$ & 35 & $34.7 \pm 0.9$ & $34.4-35.0$ \\
\hline
\end{tabular}


represented $23.48 \%$ of all captures, followed by Artibeus obscurus with $12.44 \%$, and Artibeus planirostris with $12.35 \%$ (Table 2). Total capture efficiency was 0.32 captures per net-hour. Most captured bats were frugivorous species (12 species, $35.30 \%$ of total richness and $58.25 \%$ of captures), followed by insectivorous species (11 species, $32.35 \%$ of total richness and $32.66 \%$ of captures). The remaining guilds comprised 11 species and $32.35 \%$ of total richness and $9.09 \%$ of captures. The sum of biomass of frugivorous species corresponded to $73.31 \%$ of total biomass, the insectivorous biomass corresponded to
$14.75 \%$ and the other guilds corresponded to $11.94 \%$ of total biomass (Table 1).

The estimated number of species by Chao index, for the whole sampling (44.00 \pm 8.00 species) suggests that $77.27 \%$ of the bat fauna of Ilha da Marambaia was sampled. The species accumulation curve did not show apparent stabilization (Figure 2a).

Eight species were considered as rare, since they were represented by just one capture. Most species $(\mathrm{N}=22)$ had intermediate abundances and four species were considered abundant (Table 2).

Table 2. Trophic guilds, capture efficiency, [(captures/net-hour) $\times 100)$ ], and bat species relative abundance in the sampled environments of Ilha da Marambaia, Rio de Janeiro State. Ins: insectivorous; Fru: frugivorous; Hem: hematophagous; Gli: gleaner; Oni: omnivorous; Nec: nectarivorous; Pis: piscivorous based on Kalko et al. (1996).

\begin{tabular}{|c|c|c|c|c|c|c|c|}
\hline Species & Guild & Dam & $\begin{array}{l}\text { River } \\
\text { delta }\end{array}$ & Trail & Streamlet & Residences & $\begin{array}{c}\text { Abundance } \\
(\%)\end{array}$ \\
\hline Molossus molossus & Ins & 7.86 & 23.94 & 0.16 & - & 0.16 & 23.48 \\
\hline Artibeus obscurus & Fru & 4.50 & 3.72 & 4.42 & 2.44 & 4.25 & 12.44 \\
\hline Artibeus planirostris & Fru & 4.58 & 3.27 & 5.24 & 0.49 & 4.09 & 12.35 \\
\hline Artibeus lituratus & Fru & 3.66 & 4.61 & 2.62 & 1.95 & 3.27 & 10.59 \\
\hline Carollia perspicillata & Fru & 3.21 & 0.15 & 3.44 & 0.98 & 7.04 & 9.62 \\
\hline Platyrrhinus lineatus & Fru & 1.37 & 0.89 & 0.98 & - & 1.80 & 3.62 \\
\hline Myotis riparius & Ins & 1.98 & - & 1.15 & 0.49 & 0.16 & 3.09 \\
\hline Platyrrhinus recifinus & Fru & 1.45 & - & 0.33 & - & 1.15 & 2.56 \\
\hline Artibeus fimbriatus & Fru & 0.69 & 1.34 & 0.98 & - & 1.15 & 2.56 \\
\hline Nyctinomops laticaudatus & Ins & - & 4.01 & - & - & - & 2.38 \\
\hline Desmodus rotundus & Hem & 1.14 & 0.45 & 0.33 & - & 0.98 & 2.29 \\
\hline Sturnira lilium & Fru & 1.14 & 0.30 & 0.33 & - & 0.98 & 2.21 \\
\hline Myotis nigricans & Ins & 1.37 & 0.15 & 0.16 & - & 0.49 & 2.03 \\
\hline Tonatia bidens & Gli & 0.61 & 0.45 & 0.65 & 0.49 & 0.82 & 1.85 \\
\hline Phyllostomus hastatus & Oni & 1.07 & - & 0.33 & - & 0.49 & 1.68 \\
\hline Vampyrodes caraccioli & Gli & 0.31 & 0.45 & 0.33 & 2.44 & - & 1.24 \\
\hline Anoura caudifer & $\mathrm{Nec}$ & 0.38 & 0.15 & 0.33 & - & 0.82 & 1.15 \\
\hline Molossus rufus & Ins & - & 1.64 & - & - & - & 0.97 \\
\hline Noctilio leporinus & Pis & - & 1.19 & - & - & - & 0.71 \\
\hline Trachops cirrhosus & Fru & 0.31 & - & 0.16 & - & 0.16 & 0.53 \\
\hline Vampyressa pusilla & Fru & 0.46 & - & - & - & - & 0.53 \\
\hline Micronycteris megalotis & Gli & 0.23 & - & 0.16 & - & 0.16 & 0.44 \\
\hline Glossophaga soricina & $\mathrm{Nec}$ & 0.23 & - & - & - & - & 0.26 \\
\hline Chiroderma villosum & Fru & - & - & 0.33 & - & - & 0.18 \\
\hline Cynomops abrasus & Ins & - & 0.30 & - & - & - & 0.18 \\
\hline Nyctinomops macrotis & Ins & - & 0.30 & - & - & - & 0.18 \\
\hline Anoura geoffroyi & $\mathrm{Nec}$ & 0.08 & - & - & - & - & 0.09 \\
\hline Chiroderma doriae & Fru & 0.08 & - & - & - & - & 0.09 \\
\hline Diaemus youngi & Hem & 0.08 & - & - & - & - & 0.09 \\
\hline Eptesicus brasiliensis & Ins & - & - & 0.16 & - & - & 0.09 \\
\hline Lasiurus blossevillii & Ins & - & 0.15 & - & - & - & 0.09 \\
\hline Lasiurus ega & Ins & - & 0.15 & - & - & - & 0.09 \\
\hline Lonchophylla bokermanni & $\mathrm{Nec}$ & 0.08 & - & - & - & - & 0.09 \\
\hline Saccopteryx leptura & Ins & 0.08 & - & - & - & - & 0.09 \\
\hline
\end{tabular}


There was a range from 7 to 25 species found in each environment sampled on Ilha da Marambaia, where the streamlet exhibited the lowest richness and the dam the highest. The river delta and the dam contributed with seven exclusive species each and the trail with two species. Insectivorous bats predominate at the river delta and at the dam; and frugivorous species in the other sites. Considering Margalef's richness index, no statistical difference was obtained between the environments $(\mathrm{t}=0.005, \mathrm{df}=4, \mathrm{p}=0.996)$, with maximum observed in the residential area and the minimum at streamlet (Table 3).

The qualitative similarity varied from 0.44 to 0.81 , on which the dam and the trail were the most similar environments and the river delta and the streamlet the less similar ones. The species accumulation curve for the
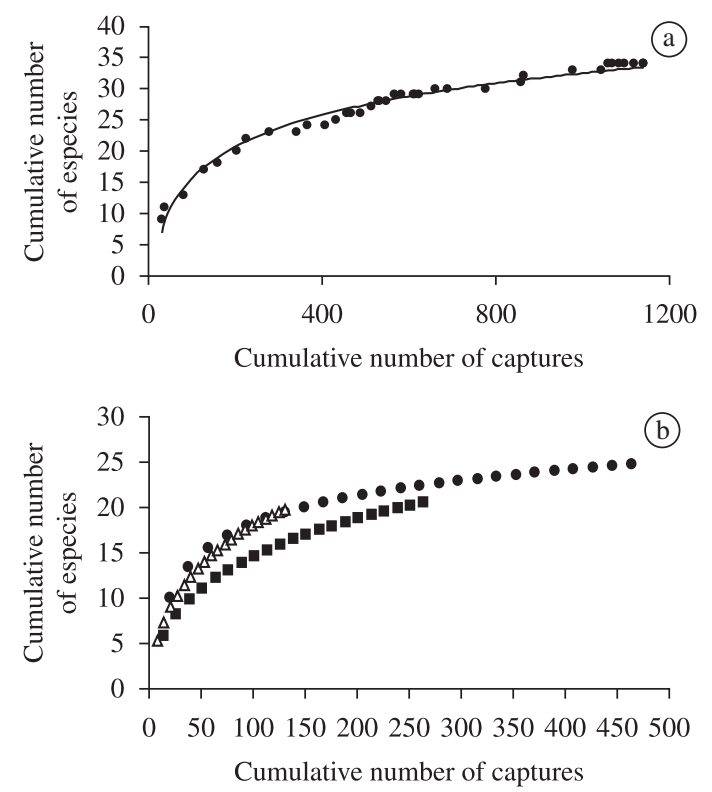

Figure 2. Cumulative curve of bat species: (a) for Ilha da Marambaia, Rio de Janeiro State. (b) For the three environments with highest sampling efforts on Ilha da Marambaia. Black dot: dam; white triangle: river delta; black square: trail. three environments with higher sampling effort did not tend to stabilize (Figure 2b).

\section{Discussion}

Ilha da Marambaia has at least 36 bat species, from which 34 were registered in this study. The previous inventory carried out by Costa and Peracchi (2005) on the island resulted in 654 captures and 16 species, from which two were not captured in the present study: Pygoderma bilabiatum (Wagner, 1843) and Diphylla ecaudata (Spix, 1823). Costa and Peracchi's study (2005) was carried out with mist nets set on trails and in the surroundings of fruiting trees, favouring the capture of frugivorous bats. Those samplings were carried out on new moon nights, and took from four to six hours of work each night, although the authors do not have available the total effort accomplished.

Atlantic Forest bat lists with more than 30 species are usually the result of a higher sampling effort. Bergallo et al. (2003) suggest at least 1,000 captures to sample the Phyllostomid richness at Atlantic Forest. Few lists obtained that number of captures and all available lists until now with more than 30 species, represent joint effort of sampling or regional samplings (e.g. Esbérard, 2003; Esbérard et al., 2006; Faria et al., 2006). At Tijuca Massif (Maciço da Tijuca), after 11 years of sampling using nets set in the understory and over 4,000 captures, 40 species were confirmed in eight sampling sites (Esbérard, 2003). Faria et al. (2006) recorded 59 species in an inventory in Southern Bahia, which included active roost searching, canopy nets and cave sampling in over 40 localities of three municipalities. Ilha da Marambaia exhibits, therefore, the largest list for just one site and with an exclusive sampling method (understory mist nets) in the whole Atlantic Forest.

Most of the bat inventories in Atlantic Forest and other Brazilian biomes exhibited one frugivorous species prevailing on captures (e.g. Peracchi and Albuquerque, 1993; Esbérard et al., 1996; Reis et al., 1996; Taddei and Pedro, 1996; Baptista and Mello, 2001; Dias et al., 2002; Esbérard, 2003; Bergallo et al., 2003; Costa and Peracchi, 2005), usually Artibeus lituratus or Carollia perspicillata.

Table 3. Richness, Margalef richness index, total captures, sampling effort, capture efficiency and exclusive and dominant species for each environment sampled on Ilha da Marambaia, Rio de Janeiro State.

\begin{tabular}{lcccccc}
\hline & Dam & Trail & River delta & Streamlet & Residences & Total \\
\hline Richness & 25 & 20 & 20 & 7 & 17 & 34 \\
Exclusive species & 7 & 2 & 7 & 0 & 0 & - \\
Captures & 484 & 138 & 321 & 19 & 171 & 1133 \\
Nights & 15 & 11 & 8 & 4 & 7 & 37 \\
Margalef richness index & 3.88 & 3.85 & 3.26 & 2.04 & 4.07 & 2.80 \\
Sampling effort (net-hour) & 1310.3 & 611.2 & 672.5 & 205.0 & 760.2 & 3559.2 \\
Efficiency (N/net-hour) & 0.37 & 0.23 & 0.48 & 0.09 & 0.22 & 0.32 \\
Dominant species & M. molossus & A. obscurus & M. molossus & A. obscurus & C. perspicillata M. molossus \\
\hline
\end{tabular}


However, other inventories exhibited dominance of species from other guilds, due to the usage of nets near known roosts (Pedro and De Marco Jr. 2008) or to the intense farming activity at the site which encourages the presence of Desmodus rotundus (e.g. Trajano, 1985; Pedro and De Marco Jr., 2008). On Ilha da Marambaia an insectivorous species, M. molossus, predominated, since it was captured at the river delta, over water or at the dam. Only in Gávea Park (Parque da Gávea), Rio de Janeiro city (see Esbérard, 2003; Esbérard and Bergallo, 2008b), a similar result was obtained, in which $M$. molossus outnumbered a frugivorous species. Insectivorous bats can outnumber the frugivorous ones at least in some places, and nets opened over water collections are more productive in capturing insectivorous bats than nets in trails (Kunz and Kurta, 1988; Voss and Emmons, 1996).

Despite the predominance of the frugivorous guild $(\mathrm{N}=12)$, there was a high richness of insectivorous species $(\mathrm{N}=11)$. Most inventories exhibit just one or two insectivorous species that are represented by few captures (e.g. Peracchi and Albuquerque, 1993; Esbérard et al., 1996; Reis et al., 1996; Taddei and Pedro, 1996; Baptista and Mello, 2001; Dias et al., 2002). Only Esbérard (2003) obtained high richness of insectivores, with nets set over a water body in Parque da Gávea and in Reserva dos Trapicheiros (Trapicheiros Reserve), Rio de Janeiro City. The frugivorous species still prevail on the total biomass observed, due to the presence of medium and large sized species of the genus Artibeus.

The present study added one species to the list of the Southern Coast of Rio de Janeiro State, Cynomops abrasus (see Esbérard et al., 2006; Esbérard and Bergallo, 2008a; Peracchi and Nogueira, 2008; Esbérard, 2009). The list of Ilha da Marambaia is $77 \%$ complete based on the Chao index, and represents $48 \%$ of total bat species recorded for Rio de Janeiro State (75 species - Esbérard and Bergallo, 2005; Peracchi and Nogueira, 2008 and unpublished data) and $78 \%$ for the Southern Coast of Rio de Janeiro State (Esbérard et al., 2006; Esbérard and Bergallo, 2008a; Peracchi and Nogueira, 2008). Failure to stabilise the accumulation curve shows that more species should be added with a higher sampling effort.

The bat community of Ilha da Marambaia exhibited higher number of species with intermediate abundances, followed by rare species, and exhibited few abundant species. Such pattern contrasts with the observed in the Amazon, where most species are rare and usually one or two species represent over 50\% of all captures (e.g. Findley, 1993; Gaston, 1994; Kalko et al., 1996; Voss and Emmons, 1996; Simmons and Voss, 1998; Hice et al., 2004). It is likely that in the Atlantic Forest, the number of rare species is not as high (see Esbérard, 2003, 2009) as in the Amazon (see Sampaio et al., 2003). Esbérard (2009) described that at two sites satisfactorily sampled in Atlantic Forest in Southeastern Brazil most species have intermediate abundances.

The results from this study reveal the importance of sampling several environments to obtain higher richness of species, since 16 species captured (47.06\% of total) were restricted to at least one of the environments analysed. No differences were found using the Margalef richness index. The high number of exclusive species resulted in small and intermediate values for Jaccard similarity observed between environments. The high richness obtained in Ilha da Marambaia shows the need for exhaustive sampling effort with nets placed in several environments, including over water bodies, in order to obtain a better sampling of the community and trophic guilds.

Despite the small area, Ilha da Marambaia shows higher diversity and richness of bats. The richness reported in this work exceeds that observed in other locals even with high sampling effort (Esberárd et al., 2006; Esbérard and Bergallo, 2008a).

Several points indicate the relevance of this island in preserving the fauna: (1) the occurrence of Vampyrodes caraccioli, only known in Atlantic Forest in Southern Bahia (Faria et al., 2006), and on this island (Bezerra et al., 2004; Peracchi and Nogueira, 2008; this work); (2) two species included in the Brazilian endangered Species List, Platyrrhinus recifinus and Lonchophylla bokermanni (Machado et al., 2005); (3) a recent survey of lizards demonstrated the occurrence of 12 species, with one endangered species, Cnemidophorus littoralis (Rocha, Araújo, Vrcibradic and Costa, 2000) (Carvalho et al., 2007) and (iv) a extensive survey confirmed 24 species of anurans, with one endemic to the island, Leptodactylus marambaiae Izecksohn, 1976 (Izecksohn and Carvalhoe-Silva, 2001) and the Ilha da Marambaia represents the southernmost limit to two species Rhinella pygmaea (Myers and Carvalho, 1952) and Xenohyla truncata (Izecksohn, 1959) (Silva et al., 2008).

Although this local was considered as a priority for the conservation for mammals, due to the high richness, endemism and isolation (Maury, 2002), until now no effective action was observed in changing the actual status to a more restrictive conservation unit.

Aknowledgements - We thank the Centro de Adestramento da Ilha da Marambaia (Training Centre of Marambaia Island) for support and the sampling permit; Dr. A. Pires, Dr. D. Dias, Dr. A. de Araújo and Dr H.R. Silva for observations on early versions of this manuscript; A D. Dias and A.L. Peracchi (Laboratório de Mastozoologia - UFRuralRJ) for confirming the identification of some voucher specimens; H.R. Silva kindly permitted the use of the map of Marambaia; A.P.F. Carvalho, A. Fernandes, J.L. Luz, D.S. França, G. Peixoto, L.A.C. Gomes for field assistance. E.C. Lourenço thanks PIBIC/CNPq/ UFRuralRJ, and L.M. Costa thanks Capes, for the respective scholarships. C.E.L Esberrard thanks $\mathrm{CNPq}$ for the Research Productivity Fellowship (process 301061/2007-6). We also thank FAPERJ and $\mathrm{CNPq}$ that financed field work and substantial sampling material (processes E-16/170.449/07 and 471983/2007-1).

\section{References}

BAPTISTA, M. and MELLO, MAR., 2001. Preliminary inventory of the bat species of the Poço das Antas Reserve, RJ. Chiroptera Neotropical, vol. 7, no. 1-2, p. 133-135. 
BERGALLO, HG., GEISE, L., BONVICINO, CR., CERQUEIRA, RD., ANDREA, PS., ESBÉRARD, CE., FERNANDEZ, FAS., GRELLE, CE., PERACCHI, A., SICILIANO, S. and VAZ, SM., 2000. Mamíferos. In BERGALLO, HG., ROCHA, CFD., ALVES, MAS. and VAN SLUYS, M. (Orgs). A fauna ameaçada de extinção do Estado do Rio de Janeiro. Rio de Janeiro: Universidade do Estado do Rio de Janeiro. p. 125-135.

BERGALLO, HG., ESBÉRARD, CEL., MELLO, MAR., LINS, V., MANGOLIN, R., MELO, GGS. and BAPTISTA. M., 2003. Bat Sampling in Atlantic Forest: how much should the minimum effort be? Biotropica, vol. 35, no. 2, p. 278-288.

BEZERRA, AMR., BAPTISTA, M., FRANCO, SM., OLIVEIRA, JÁ., 2004. A coleção de mamíferos preservados em meio líquido do Museu Nacional. Publicações Avulsas do Museu Nacional, n. 101 , p. 1-11.

CARVALHO, ALG., ARAÚJO, AFB. and SILVA, HR., 2007. Lagartos da Marambaia, um remanescente insular de Restinga e Floresta Atlântica no Estado do Rio de Janeiro, Brasil. Biota Neotropica, vol. 7, no. 2, p. 221-226.

CONDE, MMS., LIMA, HRP. and PEIXOTO, AL., 2005. Aspectos florísticos e vegetais da Marambaia, Rio de Janeiro, Brasil. In MENEZES, LFT., PEIXOTO, AL. and ARAÚJO, DSD. (Eds.). História Natural da Marambaia. Rio de Janeiro: Universidade Federal Rural do Rio de Janeiro. p. 133-168.

CHAO, A., 1984. Nonparametric estimation of the numbers of classes in a population. Scandinavian Journal of Statistics, vol. 11 , p. 265-270.

COLWELL, RK ., 2005. EstimateS: Statistical estimation of species richness and shared species from samples. Version 7.5. User's Guide and application. Available from: $<\mathrm{http}: / /$ purl.oclc. org/estimates>.

COSTA, BN. and PERACCHI, AL., 2005. Morcegos da Ilha da Marambaia. In MENEZES, LFT., PEIXOTO, AL. and ARAÚJO, DSD. (Eds.). História Natural da Marambaia. Rio de Janeiro: Universidade Federal Rural do Rio de Janeiro. p. 169-194.

DIAS, D., PERACCHI, AL. and SILVA, SSP., 2002. Quirópteros do Parque Estadual da Pedra Branca, Rio de Janeiro, Brasil (Mammalia, Chiroptera). Revista Brasileira de Zoologia, vol.19, no. 2, p. 113-140.

ESBÉRARD, CEL., 2003. Diversidade de morcegos em uma área de Mata Atlântica regenerada no sudeste do Brasil (Mammalia: Chiroptera). Revista Brasileira de Zoociências, vol. 5, no. 2, p. 189-204.

ESBÉRARD, CEL., 2007. Influência do ciclo lunar na captura de morcegos Phyllostomidae. Iheringia, Série Zooógica, vol. 97, no. 1 , p. 81- 85 .

ESBÉRARD, CEL., 2009. Capture sequence and relative abundance of bats during surveys. Revista Brasileira de Zoologia, vol. 26, no. 1 , p. 103-108.

ESBÉRARD, CEL. and BERGALLO, HG., 2005. Research on bats in the state of Rio de Janeiro, southeastern Brazil. Mastozoologia Neotropical, vol. 12, no. 2, p. 237-243.

ESBÉRARD, CEL. and BERGALLO, HG., 2006. Coletar morcegos por seis ou doze horas a cada noite? Revista Brasileira de Zoologia, vol. 22, no. 4, p. 1095-1098.

ESBÉRARD, CEL. and BERGALLO, HG., 2008a. Influência do esforço amostral na riqueza de espécies de morcegos no sudeste do Brasil. Revista Brasileira de Zoologia, vol. 25, no. 1, p. 67-73.
ESBÉRARD, CEL. and BERGALLO, HG., 2008b. Do bigger bats need more time to forage? Brazilian Journal of Biology, vol. 68 , no. 4 , p. $819-822$.

ESBÉRARD, CEL. and DAEMON, C., 1999. Novo método para marcação de morcegos. Chiroptera Neotropical, vol. 5, no. 1-2, p. 116-117.

ESBÉRARD, CEL., CHAGAS, AS., BAPTISTA, M. and LUZ, EM., 1996. Levantamento de Chiroptera na Reserva Biológica de Araras, Petrópolis, Rio de Janeiro. Revista Científica do Centro de Pesquisas Gonzaga da Gama Filho, vol. 2, p. 65-87.

ESBÉRARD, CEL., JORDÃO-NOGUEIRA, T., LUZ, JL., MELO, GG., MANGOLIN, R., JUCÁ, N., RAÍCES, DSL., ENRICI, MC. and BERGALLO, HG.,2006. Morcegos da Ilha Grande, Angra dos Reis, RJ, Sudeste do Brasil. Revista Brasileira de Zoociências, vol. 8 , no. 2, p. 147-153.

FARIA, D., SOARES-SANTOS, B. and SAMPAIO, E., 2006. Bats from the Atlantic rainforest of southern Bahia, Brazil. Biota Neotropica, vol. 6, no. 2, p. 1-13

FIDALGO, ECC., UZEDA, MC., BERGALLO, HG. and COSTA, TCC., 2007. Remanescentes da Mata Attântica no Estado do Rio de Janeiro: distribuição dos fragmentos e possibilidades de conexão. In Anais do 8 Simpósio Brasileiro de Sensoriamento Remoto. Florianópolis: INPE. p. 3885-3892.

FINDLEY, JS., 1993. Bats: a community perspective. London: Cambridge University Press. 167 p.

GASTON, KJ., 1994. Rarity: population and community biology. London: Chapman and Hall. 205 p. (Series 13)

GREGORIN, R. and TADDEI, VA., 2002. Chave artificial para a identificação de molossídeos brasileiros (Mammalia, Chiroptera). Matozoologia Neotropical, vol. 9, no. 1, p. 13-32.

HICE, C.L.P., VELAZCO, P.M. and WILLIG, M.R., 2004. Bats of the Reserva Nacional Allpahuayo-Mishana, northeastern Peru, with notes on community structure. Acta Chiropterologica, vol. 6, no. 2, p. 1-16.

IZECKSOHN, E. and CARVALHO-E-SILVA, SP., 2001. Anfíbios do município do Rio de Janeiro. Rio de Janeiro: Universidade Federal do Rio de Janeiro. 147 p

KALKO, EKV., HANDLEY, CO and HANDLEY, D., 1996. Organization, diversity and long-term dynamics of a neotropical bat community. In CODY, ML. and SMALLWOOD, JA. (Eds.). Long-term studies of vertebrate communities. New York: Academic Press. p. 503-553.

KUNZ, TH. and KURTA, A., 1988. Capture methods and holding devices. In KUNZ, TH. (Eds.). Ecological and behavior methods for the study of bats. Washington: Smithsonian Institution Press. p. 1-29.

MACHADO, ABM., MARTINS, CS. and DRUMMOND, GM., 2005. Lista da fauna brasileira ameaçada de extinção. Belo Horizonte: Fundação Biodiversitas. 160 p.

MAGURRAN, AE., 1988. Ecological diversity and its measurement. London: Croom Helm. 179 p.

MARQUES-AGUIAR, SA., 1994. A systematic review of the large species of Artibeus Leach, 1821 (Mammalia, Chiroptera) with some phylogenetic inferences. Boletim do Museu Paraense Emilio Goeldi, vol. 10, no. 1, p. 3-83.

MATTOS, CCLV., 2005. Caracterização climática da restinga da Marambaia, RJ. In MENEZES, LFT., PEIXOTO, AL. and ARAÚJO, 
DSD. (Eds.). História Natural da Marambaia. Rio de Janeiro: Universidade Federal Rural do Rio de Janeiro. p. 55-66.

MAURY, CM., 2002. Biodiversidade brasileira: avaliação e identificação de áreas e ações prioritárias para conservação, utilização sustentável e repartição dos benefícios da biodiversidade nos biomas brasileiros. Brasília: Ministério do Meio Ambiente. $404 \mathrm{p}$.

MEDELLÍN, RA., ARITA, HT. and SÁNCHEZ, OH., 1997. Identificación de los murcielagos de México. México: Associación Mexicana de Mastozoología. 83 p.

MENEZES, LFT. and ARAÚJO, DSD., 2005. Formações vegetais da restinga da Marambaia. In MENEZES, LFT., PEIXOTO, AL. and ARAÚJO, DSD. (Eds.). História Natural da Marambaia. Rio de Janeiro: Universidade Federal Rural do Rio de Janeiro. p. 67-120.

PEDRO, WA. and De MARCO Jr., P., 2008. Fragmentação de habitat e sua influência sobre as comunidades de morcegos no Brasil. In PACHECO, SM., MARQUES, RV. and ESBÉRARD, CEL. (Orgs.). Morcegos no Brasil: biologia, sistemática, ecologia e conservação. Porto Alegre: Editora Armazém Digital. p. 759-773.

PERACCHI, AL. and ALBUQUERQUE, ST., 1993. Quirópteros do Município de Linhares, Estado do Espirito Santo, Brasil (Mammalia: Chiroptera). Brazilian Journal of Biology, vol. 53, no. 4 , p. $575-581$.

PERACCHI, AL. and NOGUEIRA, MR., 2008. Quirópteros da Mata Atlântica do Sudeste do Brasil. In PACHECO, SM., MARQUES, RV. and ESBÉRARD, CEL. (Orgs). Morcegos no Brasil: biologia, sistemática, ecologia e conservação. Porto Alegre: Editora Armazém Digital. p. 279-298.

PEREIRA, LA., XEREZ, R. and PEREIRA, AMC., 1990. Ilha da Marambaia (Baía de Sepetiba): resumo fisiográfico, histórico e importância ecológica atual. Ciência e Cultura, vol. 42, no. 5-6, p. 384-389.

REIS, NR., PERACCHI, AL., MULLER, MF., BASTOS, EA. and SOARES, ES., 1996. Quirópteros do Parque Estadual do Morro do Diabo, São Paulo, Brasil (Mammalia, Chiroptera). Brazilian Journal of Biology, vol. 56, no. 1, p. 87-92.

SAMPAIO, EM., KALKO, EKV., BERNARD, E., RODRIGUEZHERRERA, B. and HANDLEY Jr., CO., 2003. A biodiversity assessment of bats (Chiroptera) in a tropical lowland rainforest of central Amazônia, including methodological and conservation considerations. Studies on Neotropical Fauna and Environment, vol. 38 , no. 1, p. 17-31.

Secretaria de Estado de Meio Ambiente e Desenvolvimento Sustentável - SEMAD, 2001. Atlas das unidades de conservação do Estado do Rio de Janeiro. São Paulo: Metalivros. 59 p.

SILVA, HR., CARVALHO, ALG. and BITTENCOURT-SILVA, GB., 2008. Frogs of Marambaia: a naturally isolated Restinga and Atlantic Forest remnant of southeastern Brazil. Biota Neotropica, vol. 8, no. 4. (on-line)

SIMMONS, NB., 2005. Order Chiroptera. In WILSON, DE. and REEDER, DM. (Eds). Mammal species of the world: a taxonomic and geographic reference. 3 ed. Baltimore: Johns Hopkins University Press. p. 312-529.

SIMONS, NB. and VOSS, RS., 1998. The mammals of Paracou, French Guiana: a neotropical lowland rainforest fauna. Bulletin of the American Museum of Natural History, vol. 237, p. 1-219.

SOBERÓN, J. and LLORENTE, J., 1993. The use of species accumulation functions for the prediction species richness. Conservation Biology, vol. 7, no. 3, p. 480-488.

TADDEI, VA. and PEDRO, W., 1996. Morcegos (Chiroptera: Mammalia) do Vale do Ribeira, Estado de São Paulo: diversidade de espécies. In Anais do 8 Seminário Regional de Ecologia. São Carlos: Universidade Federal de São Carlos. p. 911- 919.

TRAJANO, E., 1985. Ecologia de populações de morcegos cavernícolas em uma região cárstica do Sudeste do Brasil. Revista Brasileira de Zoologia, vol. 2, no. 5, p. 255-320.

VIZOTTO, LD. and TADDEI, VA., 1973. Chave para determinação de quirópteros brasileiros. Revista Faculdade Filosofia Ciências Letras São José do Rio Preto, vol. 1, p. 1-72.

VOSS, RS. and EMMONS, LH., 1996. Mammalian diversity in neotropical lowland rainforests: a preliminary assessment. Bulletin of the American Museum of Natural History, vol. 230, p. 1-115.

ZAR, JH., 1999. Biostatistical analysis. 4 ed. New Jersey: Prentice Hall. 663 p. 
